\title{
AA2024-T3 alüminyum alaşımlarına uygulanan farklı yüzey hazırlama ve pürüzlülük işlemlerinin yapıştırma bağlantılarına etkisi
}

\author{
Effect of different surface preparation and roughness treatments applied to AA2024-T3 \\ aluminum alloys in bonded joints
}

\author{
Kürşat GÜLTEKİN ${ }^{* 1, a}$, Yasemin KORKMAZ ${ }^{1, b}$ \\ ${ }^{1}$ Ondokuz Mayıs Üniversitesi, Mühendislik Fakültesi, Makine Mühendisliği Bölümü, 55270, Samsun
}

• Geliş tarihi / Received: 13.03.2021 • • Düzeltilerek geliş tarihi / Received in revised form: 07.09.2021 • Kabul tarihi / Accepted: 18.09 .2021

\begin{abstract}
Öz
Yapıştırma bağlantılarının dayanımı; yapıştırılan malzemelerin yüzeyine uygulanacak işlemlere ve yapıştırıcıların türüne göre değişiklikler göstermektedir. Özellikle yapışma yüzeyine uygulanacak yüzey işlemleri, yapıştırma bağlantılarının dayanımını arttırmakta önemli bir rol oynamaktadır. Bu çalışmada, farklı yüzey hazırlama işlemlerinin ve yüzey pürüzlülüğünün yapıştırma bağlantılarının hasar yüküne olan etkisi incelenmiş̧ir. Bu amaçla havacılık alanında kullanılan AA2024-T3 alüminyum alaşımı yapıştııllan malzeme olarak kullanılmış ve yapışma yüzeyine mekanik ve kimyasal yüzey hazırlama işlemleri uygulanmıştır. Mekanik yüzey hazırlama işlemi olarak beş farklı boyutta zımparalama, kimyasal yüzey hazırlama işlemi olarak ise sodyum dikromat/sülfürik asit, optimize edilmiş sodyum dikromat/sülfürik asit ve ferrik sülfat/sülfürik asit dağlama çözeltileri kullanılarak alüminyum alaşımlarının yapışma yüzeyleri hazırlanmıştır. Epoksi ve akrilik esaslı yapıştırıcılar, alüminyum alaşımlarının işlem görmüş yüzeylerine uygulanarak tek tesirli bağlantı numunleri üretilmiştir. Uygulanan yüzey işlemleri sonucunda alüminyum alaşımlarının yüzeylerinde oluşan aşınma ve oksit tabaka SEM tekniği ile analiz edilmiştir. Ayrıca, uygulanan farklı yüzey hazırlama işlemlerinin yapışma bağlantılarının mekanik özelliklerine etkisini incelemek amacıyla, hazırlanan bağlantı numuneleri çekme yükü altında test edilmiştir. Deneysel sonuçlar incelendiğinde, yapıştırma bağlantılarının mekanik özelliklerinin uygulanan yüzey işlemlerine bağlı olarak değiş̧tiği görülmüş̧ür. Yapış̧ırma bağlantıları için optimum yüzey pürüzlülüğü değerlerinin yapıştırıcı türünün epoksi veya akrilik olmasına bağlı olarak değiştiği gözlemlenmiştir. Ayrıca hasar yüzeyleri incelendiğinde, özel kohezif hasar oluştuğu gözlemlenmiştir.
\end{abstract}

Anahtar kelimeler: Akrilik, Çekme testi, Epoksi, Yapıştırma bağlantıları, Yüzey pürüzlülüğü

\begin{abstract}
Strength of bonding joints varies according to the applied processes on the surface of the adherend and the type of adhesives. Particularly, surface treatments to be applied to the adherend surface play an important role in increasing the strength of the adhesively bonded joints. In this study, the effect of different surface preparation processes and surface roughness on the failure load of adhesively bonded joints was investigated. For this purpose, AA2024-T3 aluminum alloy used in aviation field was used as adherend, mechanical and chemical surface preparation processes were applied to the bonding surface. Sanding in five different sizes as the mechanical surface preparation process and sodium dichromate/sulfuric acid, optimized sodium dichromate/sulfuric acid and ferric sulphate/sulfuric acid etching solutions as the chemical surface preparation process were used to prepare the bonding surfaces of aluminum alloys. Epoxy and acrylic based adhesives were applied to the treated surfaces of aluminum alloys to produce single lap joint samples. As a result of the applied surface treatments, the abrasion and oxide layer formed on the surfaces of aluminum alloys were analyzed by SEM technique. In addition, the prepared joint samples were tested under tensile load in order to examine the effect of different surface preparation processes on the mechanical properties of adhesively bonded joints. When the experimental results were examined, it was seen that the mechanical properties of the adhesive joints changed depending on the applied surface treatments. It was observed that the optimum surface roughness values for bonding joints vary depending on the type of adhesive being epoxy or acrylic. In addition, when the damage surfaces were examined, it was observed that special cohesive failure occurred.
\end{abstract}

Keywords: Acrylic, Tensile test, Epoxy, Adhesively bonded joints, Surface roughness

\footnotetext{
*a Kürşat GÜLTEKIN; kursat.gultekin@omu.edu.tr, Tel: (532) 54308 70, orcid.org/0000-0002-6790-6822

${ }^{\mathrm{b}} 0000-0002-4516-985 \mathrm{X}$
} 


\section{Giriş}

Son yıllarda, yüksek mukavemet/ağırlık oranı, korozyon direnci, elektrik ve termal iletkenlikleri gibi üstün özellikleri sayesinde alüminyum alaşımları, otomotiv ve havacılık endüstrisinde yaygın olarak kullanılmaktadır (Adin ve Turgut, 2013; Jawade vd., 2020; Adin ve Kılıçkap, 2021). Alüminyum alaşımlarının perçin, cıvata ve kaynak gibi geleneksel yöntemler ile birleştirilmesinde bazı dezavantajlar bulunmaktadır. Perçinlenmiş parçalarda önceden imal edilmiş delikler yük taşıma kapasitesini azaltırken, cıvata bağlantıları sızdırmazlık özelliğini zayıflatmaktadır (Cui vd., 2020). Yapıştırma bağlantıları; geleneksel birleştirme yöntemlerinin eksiklerini gidermesi, farklı malzemeleri birleştirmesi, homojen gerilme dağılımı gibi avantajları nedeniyle tercih edilmektedirler (Kanani vd., 2020;). Ancak bu avantajları yüksek performans sağlayacak şekilde kullanabilmek için uygun yapıştırıcı ve yapışma bağlantısı geometrisi seçimi büyük önem arz etmektedir (Boutar vd., 2016; Adin, 2017; Saraç vd., 2018). Bununla birlikte yapıştırılan malzeme türü ve malzeme yüzeyi, yapıştırma bağlantılarının mekanik özelliklerini etkileyen en önemli faktörlerdendir (Hirulkar vd., 2018). Alüminyum alaşımların; yüzey yapısı, kimyasal bileşimi ve yüzeyinde oluşan oksit tabaka yapışma dayanımını büyük ölçüde etkilemektedir (Wu vd., 2020). Yapıştırma bağlantıları üretilirken; malzeme yüzeyindeki olumsuzlukları gidermek amaciyla yüzeylere kimyasal, elektrokimyasal ve mekanik olmak üzere farklı yüzey işlemleri uygulanmaktadır. Kimyasal ve elektrokimyasal yüzey işlemlerinde, yapışma yüzeyi ince ve organik bir tabaka ile kaplanarak daha temiz ve reaktif bir yüzey elde edilir (Singh ve Kitey, 2017; Golru vd., 2015). Golru ve arkadaşları, AA1050 alüminyum alaşımlarının yüzeylerine uyguladıkları yağ alma, $\mathrm{NaOH}$ çözeltisi ile alkali dağlama ve alkali dağlama işlemi sonrası $\mathrm{HNO}_{3}$ asidi ile temizleme işlemleri sonucunda oluşan farklı yüzey pürüzlülük değerlerinin yapışma dayanımının üzerine etkisini incelemişlerdir. Alkali dağlama işlemi sonrasında yapılan asitle temizleme işleminde en iyi yapışma dayanımının elde edildiği ifade edilmiştir (Golru vd., 2015). Saleema ve arkadaşları, AA6061 alüminyum alaşımlarını $\mathrm{NaOH}$ çözeltisi ile dağlayarak ürettikleri yapıştırma bağlantılarını incelemişlerdir. Optimum yüzey pürüzlülük değeri olan $0.5 \mu \mathrm{m}$ değerinde bağlantının en yüksek kayma dayanımına ulaştığı ifade edilmiştir (Saleema vd., 2012). Xu ve arkadaşları, 2060-T8 alüminyum alaşımlarının fosforik asit anodizasyonu (PAA) yöntemi ile elde ettikleri farklı yüzey pürüzlülük değerlerinde yapışma davranışını incelemişlerdir. Elde edilen sonuçlara göre, $0.72 \mu \mathrm{m}$ yüzey pürüzlülüğ̈̈ ve $84.62 \mathrm{~mJ} / \mathrm{m}^{2}$ yüzey enerjisine sahip numunede $56.46 \mathrm{MPa}$ yapışma dayanımı gözlemlemişlerdir (Xu vd., 2016). Zhang ve arkadaşları, farklı dağlama ve anodizasyon işlemleri uygulayarak ürettikleri tek tesirli yapıştırma bağlantılarını inceledikleri çalışmada, sülfat/sülfürik asit ile dağlama+fosforik asit anodizasyonu işlemleri sonucunda maksimum pürüzlülük ve kayma dayanımı değerlerinin elde edildiğini ifade etmişlerdir. Ancak, nemli ve sıcak ortamda yapılan testler sonucunda, aşırı yüzey pürüzlülüğü nedeniyle korozyon direncinde azalma yaşandığ 1 görülmüsşür. Sülfat/sülfürik asit ile dağlama+fosforik/borik/sülfürik asit anodizasyonu sonucunda hem yüksek kayma dayanımı hem de yüksek korozyon direnci elde edilmiştir (Zhang vd., 2008).

Kumlama ve zımparalama (Salstela vd., 2016) gibi mekanik yüzey işlemleri ile yüzey pürüzlülüğ̈̈ kontrollü bir biçimde arttırılır (Singh ve Kitey, 2017). Bu sayede, yüzeyin temas alanı arttırılarak güçlü bir yapışma sağlanır. Yapıştırıcı, yüzeye etkili bir şekilde nüfuz etmezse mekanik yapışma mekanizması çalışmayabilir (Grard vd., 2020). Safari ve arkadaşları, AA2024-T3 alüminyum plakalara farklı zımparalama, farklı basınç altında kumlama ve basınç altında dört farklı sürede kum püskürtme işlemleri uygulamışlardır. Yüksek ve düşük viskoziteli epoksi yapıştırıcılar ile ürettikleri tek tesirli yapıştırma bağlantılarını incelemişlerdir. 0.6 MPa basınç altında yapılan kumlama işlemi sonucunda, $0.6 \mu \mathrm{m}$ yüzey pürüzlülügüü ile en yüksek kayma dayanımı elde edilmiştir. Ayrıca, tüm yüzey işlemlerinde en yüksek mukavemet değerleri, yüksek viskoziteli yapıştırıcı kullanılan bağlantılarında gözlemlenmiştir (Safari vd., 2020). Ghumatkar ve arkadaşları, alüminyum 6063 alaşımlarının yapışma yüzeyinde P50, P80 ve P120 zımpara kağıtları ile elde ettikleri farklı pürüzlülük değerlerinin, yapıştırma bağlantılarının mekanik özellikleri üzerindeki etkisini incelemişlerdir. P120 zımpara kağıdı ile elde edilen optimum yüzey pürüzlülüğünün etkisiyle bağlantının maksimum kayma dayanımı değerine ulaştığı ifade edilmiştir (Ghumatkar vd., 2017). Xing ve arkadaşları, 3003 alüminyum plakaları, epoksi reçine ve akrilat yapıştırıcı ile yapıştırarak ürettikleri numunelerin, farkl1 boyutlarda zimparalama (P80, P320, P600) işlemleri sonucunda yapışma dayanımlarını incelemişlerdir. P600 zımpara kağıdı ile yüzeyde çok az miktarda pürüzlülük oluşması yapışmayı olumsuz etkilemiştir. P80 zımpara kağıdının, plaka yüzeyini çok pürüzlü hale getirmesi sonucu plakayapıştırıcı arasında oluşan boşlukların yapışma 
gücünü azalttığı gözlemlenmiştir. Yapışma dayanımı için en iyi sonuç, epoksi kullanılarak üretilen bağlantıda P320 zımpara kağıdı ile elde edilmiştir (Xing vd., 2020).

Yapılan çalışmada, farklı yüzey hazırlama işlemlerinin ve yüzey pürüzlülüğünün yapıştırma bağlantılarının hasar yüküne etkisi incelenmiştir. Bu amaçla havacılık alanında kullanılan AA2024T3 alüminyum alaşımı yapıştırılan malzeme olarak kullanılmış ve yapışma yüzeyine mekanik ve kimyasal yüzey hazırlama işlemleri uygulanmıştır. Mekanik yüzey hazırlama işlemi olarak beş farklı boyutta zimparalama (P80, P180, P400, P800 ve $\mathrm{P} 1200$ ), kimyasal yüzey hazırlama işlemi olarak ise sodyum dikromat/sülfürik asit (S1), optimize edilmiş sodyum dikromat/sülfürik asit (S2) ve ferrik sülfat/sülfürik asit (S3) dağlama çözeltileri kullanılarak AA2024-T3 alüminyum alaşımlarının yapışma yüzeyleri hazırlanmıştır. Epoksi ve akrilik esaslı yapıştırıcılar ile hazırlanan numuneler kullanılarak tek tesirli bağlantı numuneleri üretilmiştir. Uygulanan yüzey işlemleri sonucunda AA2024-T3 alüminyum alaşımlarının yüzey morfolojisi (aşınma ve oksit tabaka) SEM tekniği ile analiz edilmiştir. Ayrıca, uygulanan farklı yüzey hazırlama işlemlerinin yapışma bağlantılarının mekanik özelliklerine etkisini incelemek amaciyla, hazırlanan bağlantı numuneleri çekme yükü altında test edilmiştir.

\section{Materyal ve metot}

\subsection{Malzemeler}

AA2024-T3 alüminyum alaşımı yüksek mukavemet, korozyon dayanımı ve işlenebilirliği gibi üstün özellikleri nedeniyle havacıllk alanında, özellikle uçak kanadı ve gövdesinde, yaygın olarak kullanılmaktadır. Yapılan çalışmada, bahsedilen özelliklerinden dolay1 AA2024-T3 alüminyum alaşımı kullanılmıştır. AA2024-T3 alaşımının gerilme-şekil değiştirme eğrisi ve mekanik özellikleri Şekil 1'de, kimyasal bileşimi ise Tablo 1 'de verilmiştir.

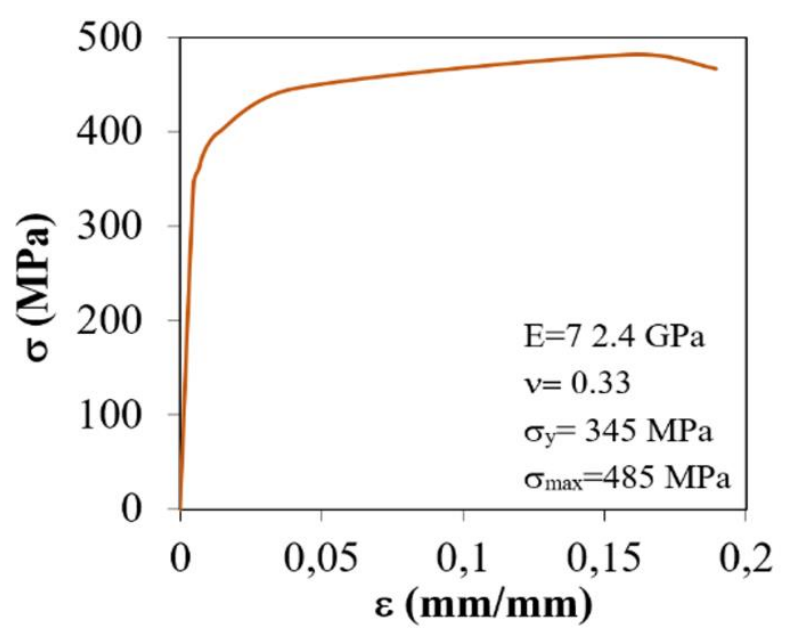

Şekil 1. AA2024-T3 alaşımının gerilme-şekil değiştirme eğrisi ve mekanik özellikleri (Gültekin vd., 2015)

Tablo 1. AA2024 alüminyum alaşımının kimyasal bileşimi (Natalia vd., 2016)

\begin{tabular}{cccccccccc}
\hline Element & $\mathbf{C u}$ & $\mathbf{M g}$ & $\mathbf{M n}$ & $\mathbf{F e}$ & $\mathbf{Z n}$ & $\mathbf{S i}$ & $\mathbf{T i}$ & $\mathbf{C r}$ & $\mathbf{A l}$ \\
\hline \% A Ăg. & 4.55 & 1.49 & 0.45 & 0.17 & 0.16 & 0.10 & 0.02 & $\leq 0.01$ & Kalan \\
\hline
\end{tabular}

AA2024-T3 alaşımlarını birleştirmek için çift bileşenli yapısal epoksi ve akrilik yapıştırıcılar kullanılmıştır. Epoksi olarak Araldite 2011 (Huntsman), akrilik olarak ise G-FORCE (Erde) yapıştırıcıları kullanılmıştır. Kullanılan yapıştırıcılar sıvı formda olup yüzeye etkili nüfuz edebilmekte ve alüminyum alaşımlarının yapıştırılmasında başarılı bir etkiye sahiptir. Araldite 2011 yapısal epoksi yapıştırıcısı 1:0.8 oranında epoksi ve sertleştiriciden oluşmakta ve $60^{\circ} \mathrm{C}$ 'de 75 dakika sürede kürleşmektedir. G-
FORCE akrilik yapıştırıcısı ise 1:1 karışım oranına sahiptir ve oda sıcaklığında kürleşmektedir. Çalışmada kullanılan yapıştırıcıların mekanik özellikleri Tablo 2'de verilmiştir.

Dağlama çözeltilerinin hazırlanmasında kullanılan sodyum dikromat $\left(\mathrm{Na}_{2} \mathrm{Cr}_{2} \mathrm{O}_{7}\right)$, ferrik sülfat $\left(\mathrm{Fe}_{2}\left(\mathrm{SO}_{4}\right)_{3}\right)$, sülfürik asit $\left(\mathrm{H}_{2} \mathrm{SO}_{4}\right)$, alüminyum sülfat $\left(\mathrm{Al}_{2} \mathrm{O}_{12} \mathrm{~S}_{3} 16 \mathrm{H}_{2} \mathrm{O}\right)$ ve bakır sülfat $\left(\mathrm{CuSO}_{4} 5 \mathrm{H}_{2} \mathrm{O}\right)$ kimyasalları Sigma Aldrich (Türkiye)'den temin edilmiştir.

Tablo 2. Yapıştırıcıların mekanik özellikleri (Özer and Erbayrak, 2016)

\begin{tabular}{cccc}
\hline Yapıştırıcı & Çekme dayanımı (Mpa) & Poisson oranı (v) & Elastisite modülü (Mpa) \\
\hline Araldite 2011 & 33 & 0.41 & 1600 \\
G-Force & 22 & 0.36 & 1300 \\
\hline
\end{tabular}




\subsection{Numunelerin hazırlanmast}

\subsubsection{Yüzey işlemleri}

Yapıştırma bağlantısı üretiminin öncesindeki en kritik nokta yapışma yüzeyinin hazırlığıdır. Yapıştırıcı ile yapışma yüzeyin tamamen temas etmesi gerekmektedir. Bu nedenle yapıştırıcının temas edeceği yüzey, olabilecek en temiz halde bulunmalıdır. Olası bir kirli yüzey durumunda ara yüzeyde bulunan maddeler (yağ, kir vb.) yapışmayı engelleyici rol oynar. $\mathrm{Bu}$ durum ise yapıştırma bağlantısının dayanımını azaltmaktadır. $\mathrm{Bu}$ nedenle, yapılan çalışmada alüminyum numuneler ilk olarak aseton ile yıkanmıştır.

Mekanik yüzey işlemi olarak alüminyum alaşımları; P80, P180, P400, P800 ve P1200 olmak üzere beş farklı boyutta zımpara kağıdı ile aşındırılmıştır. Ardından alkalin esaslı bir temizleyici ile zımparalama işlemi sonrası oluşan kir temizlenmiştir. Numuneler yıkandıktan sonra aseton içerisinde 15 dakika bekletilmiştir. Daha sonra numuneler $80^{\circ} \mathrm{C}$ 'de steril bir etüv içerisinde kurutulmuştur. Kimyasal yüzey işlemi olarak, sodyum dikromat/sülfürik asit (S1), optimize edilmiş sodyum dikromat/sülfürik asit (S2), ferrik sülfat/sülfürik asit (S3) dağlama işlemleri uygulanmıştır. Dağlama işlemi öncesinde numunelerin yüzeyindeki yağ ve kir gibi yapışmayı olumsuz etkileyecek yabanc1 unsurlar aseton ile temizlenmiştir. Daha sonra numuneler P1200 zımparalama işlemi ile mekanik olarak
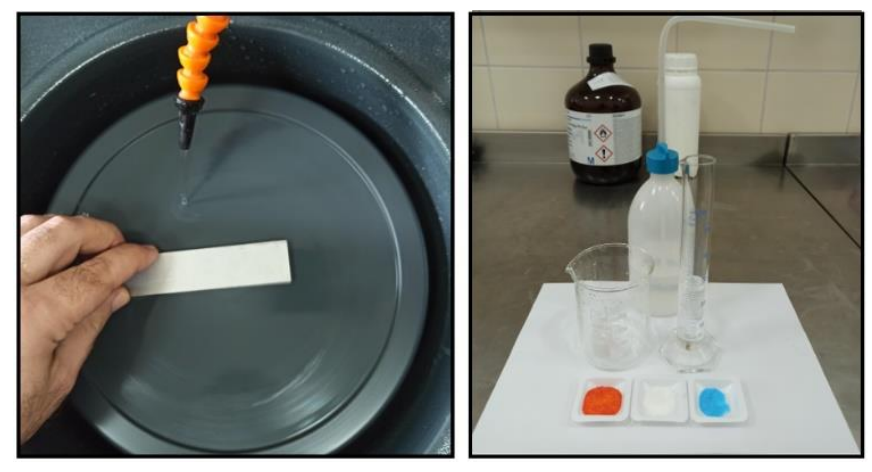

Şekil 2. AA2024-T3 alaşımlarının yüzey hazırlığı

Ferrik sülfat/sülfürik asit (S3) çözeltisi $150 \mathrm{~mL}$ olarak hazırlanmıştır. İlk olarak beher içerisine bir miktar saf su konulmuştur. Saf su üzerine yavaşça $27 \mathrm{~mL}$ sülfürik asit $\left(\mathrm{H}_{2} \mathrm{SO}_{4}\right)$ ilave edilip karıştırıldıktan sonra, çözeltiye $22.5 \mathrm{~g}$ ferrik sülfat $\left(\mathrm{Fe}_{2}\left(\mathrm{SO}_{4}\right)_{3}\right)$ ilave edilmiştir. Çözelti, saf su ile 150 mL'ye tamamlanmıştır. Hazırlanan çözelti içerisine daldırılan alüminyum numuneler 65$70^{\circ} \mathrm{C}$ 'de ki çözeltide 15 dakika boyunca dağlanmıştır. Diğer dağlama yöntemlerinde olduğu aşındırılmıştır. Ardından alkalin esaslı deterjan ile temizlenen numuneler sonrasinda 15 dakika asetonda bekletilmiş ve ardından kurutulmuştur. Dağlama işlemi öncesi numuneler hazır hale getirilmiştir.

Sodyum dikromat/sülfürik asit (S1) çözeltisi, 30 $\mathrm{mL}$ saf su içerisine yaklaşı $2.35 \mathrm{~g}$ sodyum dikromat $\left(\mathrm{Na}_{2} \mathrm{Cr}_{2} \mathrm{O}_{7}\right)$ ve $23.5 \mathrm{~mL}$ sülfürik asit $\left(\mathrm{H}_{2} \mathrm{SO}_{4}\right)$ ilave ederek hazırlanmıştır. Çözelti üzerine saf su eklenerek $150 \quad \mathrm{~mL}$ 'ye tamamlanmıştır. AA2024-T3 alaşımları 65$70^{\circ} \mathrm{C}$ 'de hazırlanan çözeltide 15 dakika süreyle dağlanmıştır. Daha sonra numuneler saf su ve etil alkol ile yıkanarak kurutulmuştur.

Optimize edilmiş sodyum dikromat/sülfürik asit (S2) çözeltisi ise alüminyum sülfat $\left(\mathrm{Al}_{2} \mathrm{O}_{12} \mathrm{~S}_{3} 16 \mathrm{H}_{2} \mathrm{O}\right)$ ve bakır sülfat $\left(\mathrm{CuSO}_{4} 5 \mathrm{H}_{2} \mathrm{O}\right)$ katkısı ile optimize edilmiştir. $\mathrm{Bu}$ amaçla $\mathrm{S} 2$ çözeltisi hazırlığının ilk aşamasında, $70 \mathrm{~mL}$ saf su üzerine yaklaşık $2.6 \mathrm{~g}$ alüminyum sülfat $\left(\mathrm{Al}_{2} \mathrm{O}_{12} \mathrm{~S}_{3} 16 \mathrm{H}_{2} \mathrm{O}\right)$ ve $0.58 \mathrm{~g}$ bakır sülfat $\left(\mathrm{CuSO}_{4} 5 \mathrm{H}_{2} \mathrm{O}\right)$ ilave edilmiş ve çözünene kadar karıştırılmıştır. Daha sonra çözelti üzerine sırasıyla yaklaşık $4.95 \mathrm{~g}$ sodyum dikromat $\left(\mathrm{Na}_{2} \mathrm{Cr}_{2} \mathrm{O}_{7}\right)$ ve 27 $\mathrm{mL}$ sülfürik asit $\left(\mathrm{H}_{2} \mathrm{SO}_{4}\right)$ ilave edilerek karıştırılmıştır. Son aşamada, çözelti $150 \mathrm{~mL}$ 'ye tamamlanana kadar saf su ilave edilmiştir. Alüminyum numuneler $65-70^{\circ} \mathrm{C}$ 'de hazırlanan dağlama çözeltisi içerisinde 15 dakika boyunca dağlanmıştır (Şekil 2). Dağlanan numuneler saf su ve etil alkol ile yıkanarak kurutulmuştur.
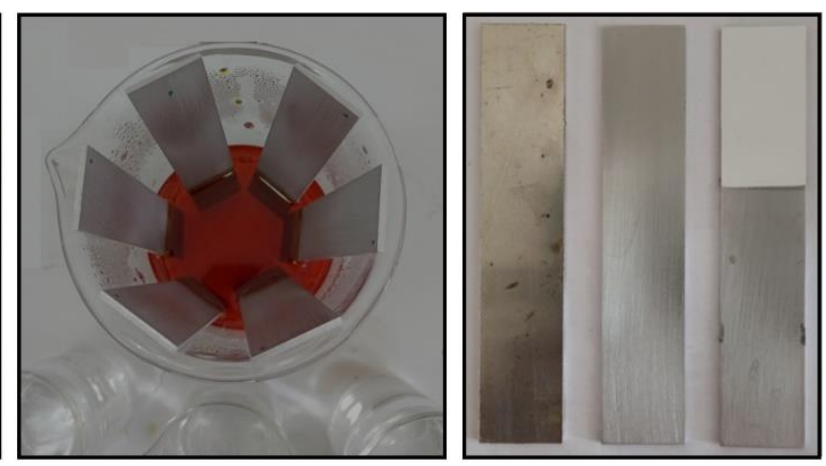

gibi numuneler saf su ve etil alkol ile yıkanmış ve kurutulmuştur. Hazırlanan tüm numunelerin pürüzlülük değerleri (Ra) PCE-RT 2000 marka pürüzlülük ölçüm cihazı ile ölçülmüştür. Numunelerin yüzeyi üzerinde oksit tabakası oluşmaması için 48 saat içerisinde yapıştırılması gerekmektedir. $\mathrm{Bu}$ amaçla hazırlanan tüm numuneler yapıştırma işlemine kadar desikatör içerisinde muhafaza edilmiştir (Şekil 3). 

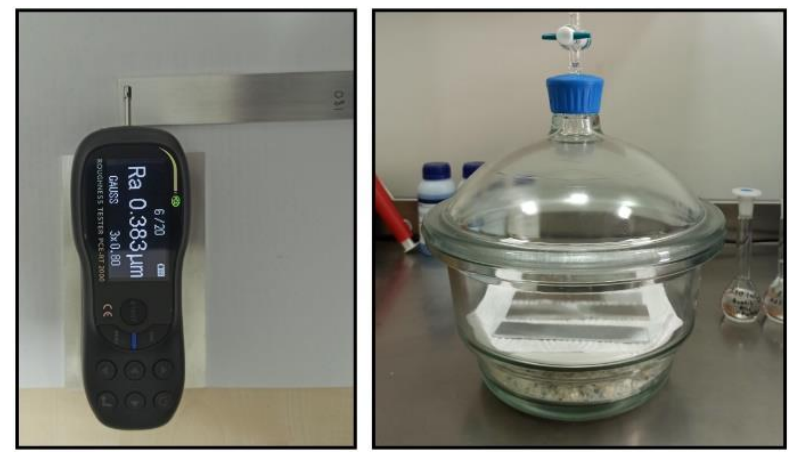

\subsubsection{Tek tesirli bindirme bağlantılarının üretimi}

Yapılan çalışmada, AA2024-T3 alüminyum alaşımlarına uygulanan farklı yüzey işlemlerinin yapışma dayanımına etkisini incelemek amacıyla, epoksi ve akrilik esaslı yapıştırıcılar kullanılarak tek tesirli yapıştırma bağlantıları üretilmiştir. Üretilen tek tesirli yapıştırma bağlantısı numunelerinin geometrisi Şekil 4'de verilmiştir.

Şekil 3. Pürüzlülük ölçümü ve numunelerin muhafaza edilmesi

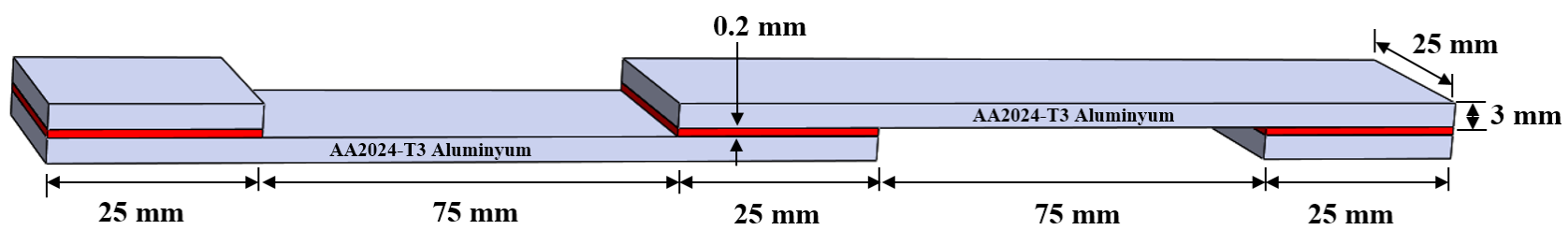

Şekil 4. Tek tesirli bindirme bağlantısının geometrisi
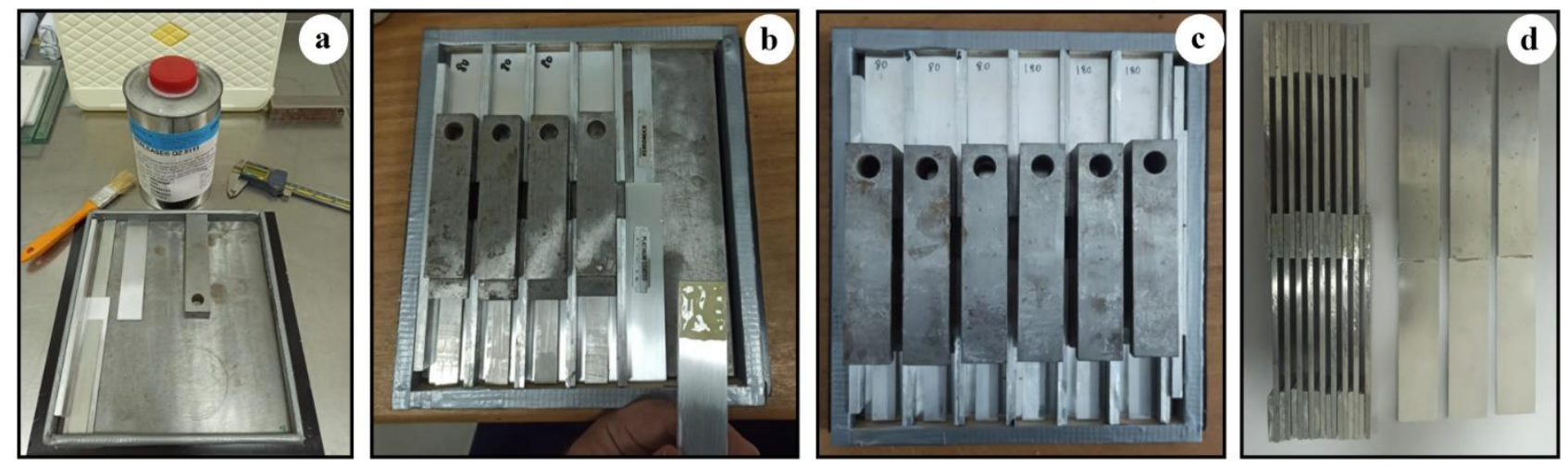

Şekil 5. Tek tesirli bindirme bağlantılarının üretim aşamaları

Yapıștırma bağlantıları üretilirken yapıștırıcının kalınlığını ve bindirme uzunluğunu Şekil 4'de belirtilen ölçülerde ayarlamak için özel olarak hazırlanmış bir kalıp kullanılmıştır (Şekil 5a). Numunelerin kalıptan kolay ayrılabilmesi için yapıştırma işlemi öncesinde kalıp ve kalıp aparatları üzerine silikon kalıp ayırıcı uygulanmıştır. Tek tesirli yapıştırma bağlantılarını elde edebilmek için; numunenin işlem görmüş yüzeyine yapıştırıcı sürülmüştür. Yapıştırıcı kalınlığını tüm bağlantılarda $0.2 \mathrm{~mm}$ olacak şekilde aparat yardımıyla ayarlanmıştır (Şekil 5b). Yapıştırılan numunelerde bulunan fazla yapıştırıcının eşit miktarda taşmasını sağlamak amacıyla her bağlantı üzerine eşit ağırlıklar yerleştirilmiştir (Şekil 5c). Hazırlanan numunelere fırın içerisinde kürleșme ișlemi uygulanmıștır. Epoksi yapıştırıcı kullanılarak üretilen tek tesirli bağlantı numuneleri $60^{\circ} \mathrm{C}^{\prime} \mathrm{de} \quad 75 \mathrm{dk}$ sürede kürleştirilirken, akrilik yapıştırıcı kullanılarak üretilen bağlantı numuneleri ise oda sıcaklığında kürleştirilmiştir. Kürleşen numuneler, soğuması için oda sıcaklığında bekletilmiştir. Bağlantı numunelerinden taşan fazla yapıştırıcılar temizlenerek çekme testi öncesi numuneler hazır hale getirilmiştir (Şekil 5d).

\section{3. Çekme testi}

Her parametre için üç adet çekme numunesi hazırlanmış ve tüm deney numuneleri INSTRON marka üniversal çekme cihazında $1 \mathrm{~mm} / \mathrm{dk}$ hızla, $24^{\circ} \mathrm{C}$ ve $\% 42$ bağ 11 nem ortamında test edilmiştir. Tek tesirli bağlantı numunelerine uygulanan sınır şartları ile kuvvetler Şekil 6'da gösterilmiştir. Deneysel parametreler ise Tablo 3 'te verilmiştir. 


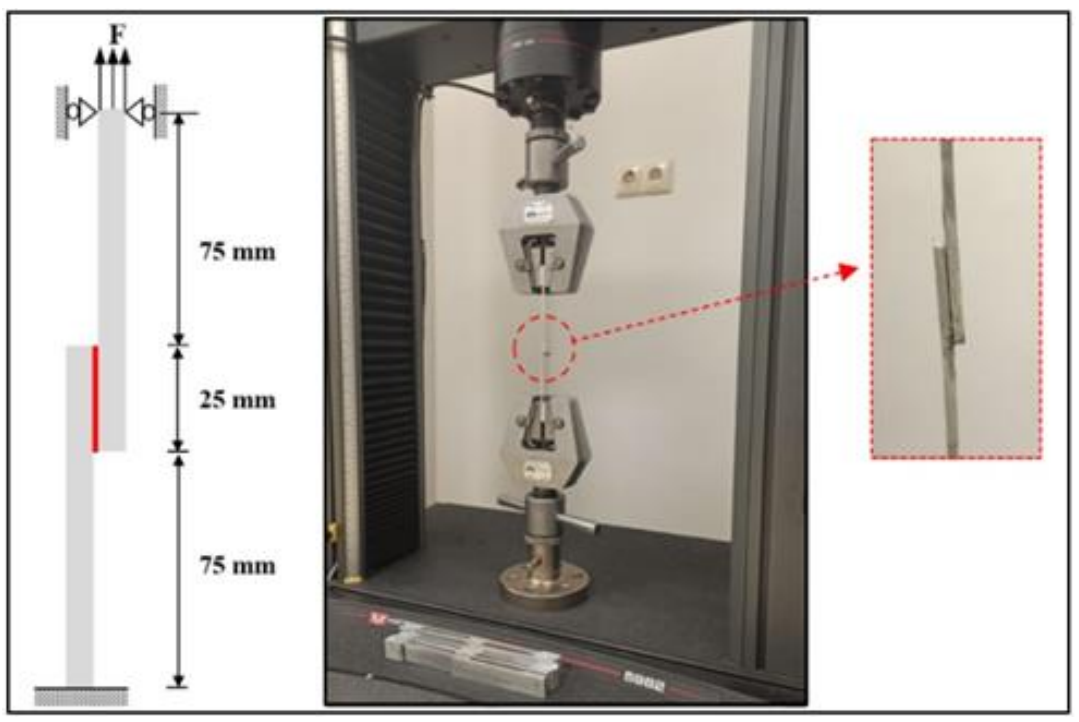

Şekil 6. Sınır şartları ve çekme testi

Tablo 3. Deneysel parametreler

\begin{tabular}{|c|c|c|}
\hline Yapıştırıcı & $\begin{array}{l}\text { Yüzey } \\
\text { işlemleri }\end{array}$ & Parametre \\
\hline \multirow{8}{*}{ 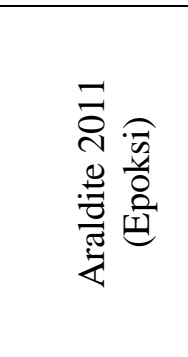 } & P80 & E-80 \\
\hline & P180 & E-180 \\
\hline & P400 & E-400 \\
\hline & P800 & E-800 \\
\hline & P1200 & E-1200 \\
\hline & S1 dağlama & E-S1 \\
\hline & S2 dağlama & E-S2 \\
\hline & S3 dağlama & E-S3 \\
\hline \multirow{8}{*}{ 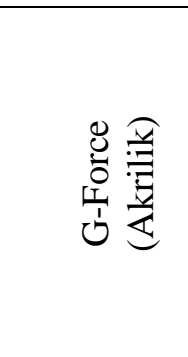 } & P80 & A- 80 \\
\hline & P180 & A-180 \\
\hline & $\mathrm{P} 400$ & A-400 \\
\hline & P800 & A-800 \\
\hline & P1200 & A- 1200 \\
\hline & S1 dağlama & $\mathrm{A}-\mathrm{S} 1$ \\
\hline & S2 dağlama & $\mathrm{A}-\mathrm{S} 2$ \\
\hline & S3 dağlama & A-S3 \\
\hline
\end{tabular}

\section{Bulgular ve tartışma}

\subsection{Yüzey ișlemlerinin AA2024-T3 alüminyum alaşımlarına etkisi}

AA2024-T3 alüminyum alaşımlarına uygulanan farklı boyutlardaki zımparalama (P80, P180, P400, $\mathrm{P} 800$ ve $\mathrm{P} 1200)$ ve üç farklı dağlama işlemi (sodyum dikromat/sülfürik asit (S1), optimize edilmiş sodyum dikromat/sülfürik asit (S2) ve ferrik sülfat/sülfürik asit (S3) dağlama) sonucunda elde edilen yüzey pürüzlülük değerleri Tablo 4 'te ve SEM görüntüleri ise Şekil 7'de verilmiştir.
Tablo 4. AA2024-T3 alüminyum alaşımlarının yüzey pürüzlülüğü değerleri

\begin{tabular}{cc}
\hline Yüzey işlemleri & Ra $(\boldsymbol{\mu m})$ \\
\hline P80 & $1.15 \pm 0.06$ \\
P180 & $0.40 \pm 0.06$ \\
P400 & $0.20 \pm 0.1$ \\
P800 & $0.13 \pm 0.06$ \\
P1200 & $0.09 \pm 0.02$ \\
S1 dağlama & $0.64 \pm 0.05$ \\
S2 dağlama & $0.89 \pm 0.1$ \\
S3 dağlama & $0.73 \pm 0.08$ \\
\hline
\end{tabular}

Tablo 4'te verilen sonuçlar incelendiğinde; mekanik olarak aşındırılmış yüzeyler daha büyük pürüzlülük değerleri gösterirken, yüzeylerinde ise düzensiz doğrultuda yönelimler göstermektedir (Şekil 7). Yüzey morfolojisinden de görüldüğü üzere (Şekil 7e) P1200 zımparalama işlemi ile en düşük pürüzlülük değeri $(0,09 \mu \mathrm{m})$ elde edilmiştir. Zımpara kağıdı numarası ile ters oranda artan pürüzlülük değerleri doğrultusunda, P80 zımparalama işlemi sonucu elde edilen yapışma yüzeyinde ise nispeten yüksek sayıda derin mikro düzensizlikler ve bunun sonucunda maksimum pürüzlülük değeri $(1.15 \mu \mathrm{m})$ elde edilmiştir. Bununla birlikte, dağlama işlemleri ile oluşan yüzeyler büyük oranda farkl1lıklar göstermektedir. Dağlanmış numunelere ait SEM görüntüleri incelendiğinde; maksimum pürüzlülük değerinin elde edildiği P80 zımparalama işlemine göre nispeten düşük pürüzlülük değerleri gösteren dağlama işlemleri ile daha homojen ve düzgün dağılım gösteren yüzeyler elde edilmiştir. 


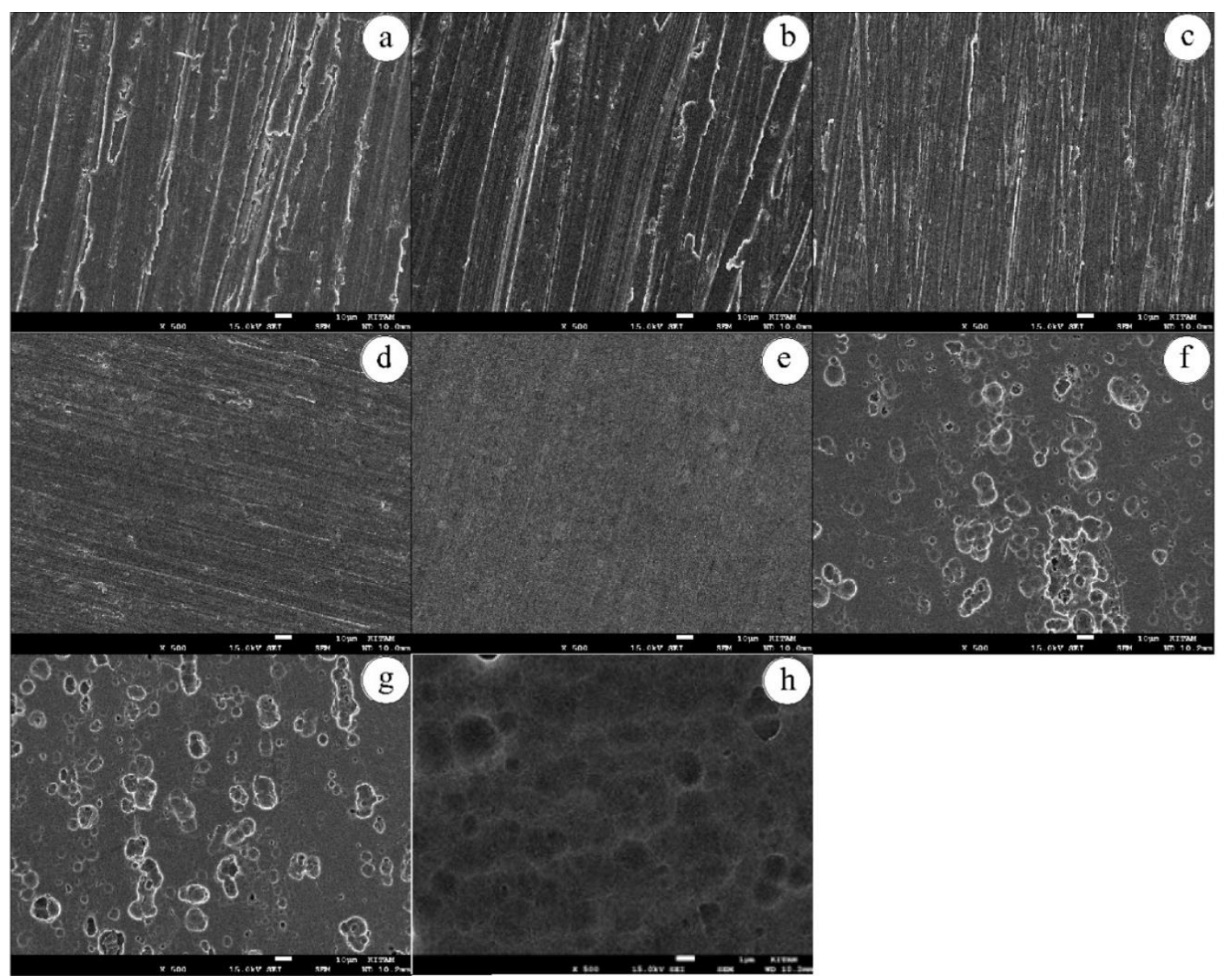

Şekil 7. SEM görüntüleri (a) P80, (b) P180, (c) P400, (d) P800, (e)P1200, (f) S1, (g) S2, (h) S3

Bunun yanı sıra, yapış̧ma yüzeylerinde oluşan ve yapışma dayanımının artmasına önemli ölçüde katk1 sağlayan gözenekli ince oksit tabakalar görülmektedir. Oluşan bu gözenekli oksit tabaka, ara yüzeydeki temas alanını ve yüzey enerjisini büyük oranda arttırarak hidrofilik bir yüzey oluşturmaktadır. Hidrofilik yüzey ise yapıştırıcı ve yüzey arasındaki kimyasal bağların ve sslanabilirliğin artmasında önemli bir rol oynamaktadır. Bu sayede yapıştırıcı yüzeye daha etkili nüfuz ederek mekanik kilitlenmeyi arttırmaktadır (Şekil 8).

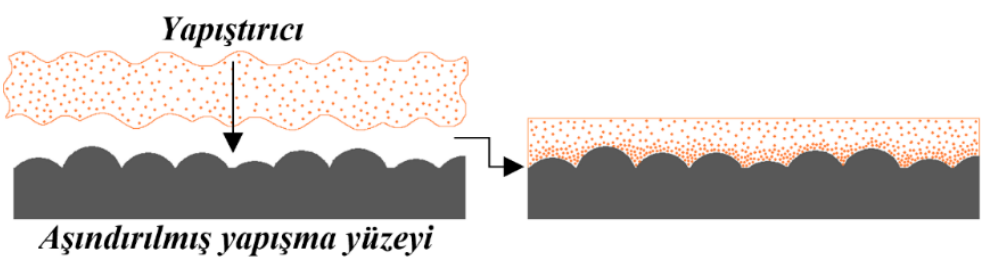

Şekil 8. Mekanik kilitlenme mekanizması

Daha gözenekli ve homojen bir yapışma yüzeyi, temas alanını artırarak, yapıştırıcı ve yapıştırılan malzeme arasında oluşan mekanik kilitlenmeyi iyileştirmektedir. $\mathrm{Bu}$ durum da bağlantıların mekanik özelliklerine olumlu etki sağlamaktadır.

\subsection{Yüzey işlemlerinin yapıştırma bağlantılarının hasar yüküne etkisi}

Yapıştırma bağlantılarında, yapıştırıcı türünün ve uygulanan farklı yüzey işlemlerinin, hasar yüküne olan etkisini incelemek amaciyla her bir parametreden 3 adet numune test edilmiş ve elde edilen ortalama hasar yükleri Şekil 9 ve Şekil 10'da verilmiştir.

Epoksi yapıştırıcı kullanılarak üretilen tek tesirli bağlantı numunelerinin ortalama hasar yükleri Şekil 9'da verilmiştir. Sonuçlar incelendiğinde, yapıştırılan malzemelere uygulanan farklı yüzey ișlemlerine bağlı olarak hasar yükünün önemli miktarda değiştiği görülmektedir. Farklı boyutta 
zımpara kağıtları ile aşındırılarak hazırlanan bağlant1 numunelerinin (E-80, E-180, E-400, E800 ve E-1200) çekme testi sonuçlar1 incelendiğinde, maksimum hasar yükünün $0,13 \mu \mathrm{m}$ $\mathrm{Ra}$ pürüzlülük değerinde elde edildiği görülmektedir. Elde edilen ortalama hasar yükü $1.15 \mu \mathrm{m}$ Ra pürüzlülük değerine sahip numuneler ile birleştirilmiş yapıştırma bağlantıları ile kıyaslandığında hasar yükü yaklaşık \%20 oranında artmıştır. Benzer şekilde $0.40 \mu \mathrm{m}$ ve $0.20 \mu \mathrm{m} \mathrm{Ra}$ yüzey pürüzlülüğüne sahip numuneler ile kıyaslandığında ise hasar yükü sırasıyla \%16 ve \%10 oranında artış göstermiştir. $0.09 \mu \mathrm{m}$ Ra yüzey pürüzlülügüne sahip AA2024-T3 alüminyum alaşımlarıla birleştirilmiş yapş̧ırma

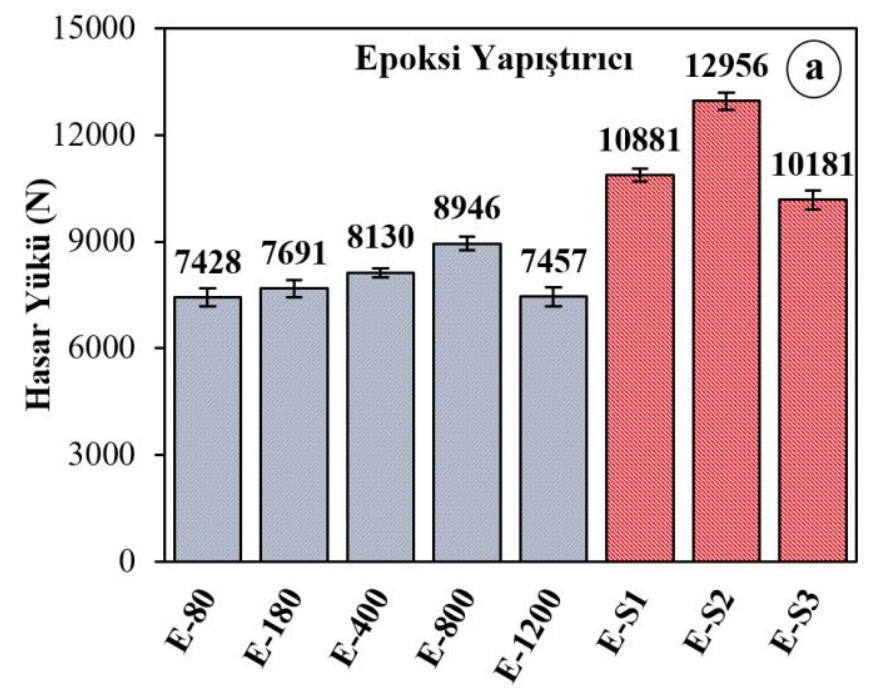

bağlantılarının ortalama hasar yükü $7457 \mathrm{~N}$ olup, $0.13 \mu \mathrm{m}$ Ra yüzey pürüzlülüğüne sahip numunelere kıyasla hasar yükünde \%17 oranında azalma görülmüştür. Bağlantı numunelerinin yüzeylerinin pürüzlülük değeri arttıkça, ara yüzeydeki temas alanı artmaktadır. Ancak, yüzeyin aşırı pürüzlü olması durumunda yapıştırıcının gözeneklere nüfuz etmesi zorlaşmakta ve böylece yüzeyi tam olarak ıslatamamaktadır. Bu durum bağlantıların mekanik özelliklerini olumsuz etkilemektedir. Mekanik yüzey hazırlama yöntemi kullanılarak üretilen bağlantılarda, optimum $0.13 \mu \mathrm{m} \mathrm{Ra}$ pürüzlülük değeri, ideal bir kilitlenme mekanizması oluşmaktadır.

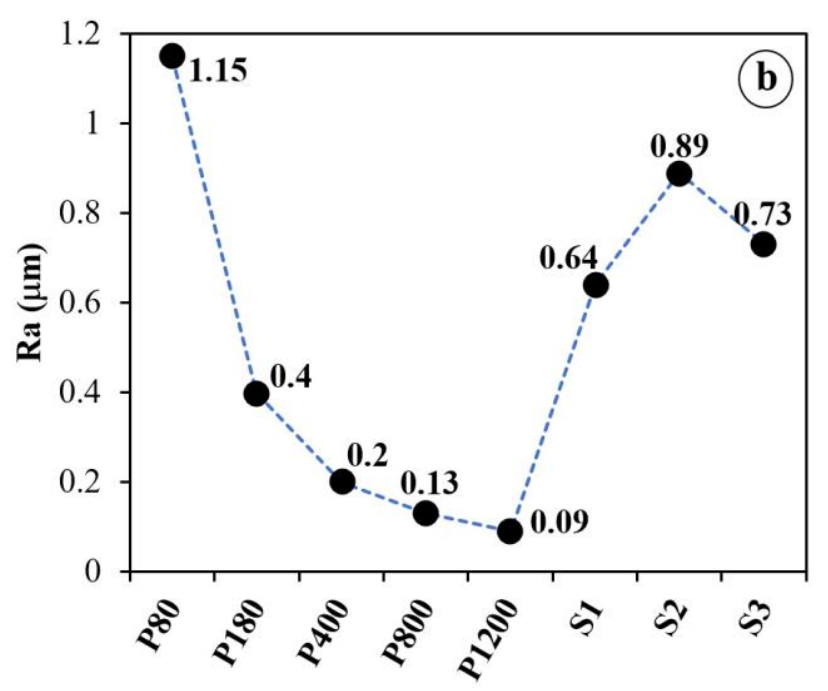

Şekil 9. (a) Epoksi yapıştırıcı (Araldite 2011) ile birleştirilmiş bağlantıların ortalama hasar yükleri, (b) Yüzey pürüzlülük değerleri

Farklı kimyasal dağlama işlemleri ile hazırlanan (E-S1, E-S2 ve E-S3) bağlantı numunelerinin ortalama hasar yükleri incelendiğinde ise, optimize edilmiş sodyum dikromat sülfürik asit (S2) ile dağlama işlemi sonucunda yapışma yüzeyinde oluşan $0.89 \mu \mathrm{m} \mathrm{Ra}$ pürüzlülüğü ile $12956 \mathrm{~N}$ maksimum ortalama hasar yükü değeri elde edilmiştir. $\mathrm{Bu}$ hasar yükü değerinin, sodyum dikromat/sülfürik asit (S1) çözeltisi ile dağlanan numuneler ile kıyaslandığında $(0.64 \mu \mathrm{m} \mathrm{Ra}) \% 19$ oranında artış, ferrik sülfat/sülfürik asit (S3) çözeltisi ile dağlanan numuneler ile kıyaslandığında ise $(0.73 \mu \mathrm{m} \mathrm{Ra}) \% 27$ oranında artış sağladığı gözlemlenmiştir.

Tüm yüzey işlemlerinin sonuçları analiz edildiğinde, maksimum ortalama hasar yükü değeri $0.89 \mu \mathrm{m}$ Ra (S2 çözeltisi) yüzey pürüzlülüğü değerine sahip yapıştırma bağlantılarında elde edilmiştir. Maksimum hasar yükü değeri, farkl1 boyutta zımpara kağıtları ile elde edilen $1.15 \mu \mathrm{m}$, $0.40 \mu \mathrm{m} 0.20 \mu \mathrm{m} 0.13 \mu \mathrm{m}, 0.09 \mu \mathrm{m}$ Ra pürüzlülük değerlerine sahip yapıştırma bağlantılarının ortalama hasar yükleriyle karşılaştırıldığında sirasiyla $\% 74, \% 68, \% 59, \% 45$ ve $\% 74$ oranlarında artış sağlanmıştır. Dağlama işlemleri sonrasında yüzeyde oluşan homojen gözenekli yap1 ve ince oksit tabaka sayesinde, yapıştırıcı ile yapıştırılan malzeme arasında iyi bir tutunma gerçekleşmiştir. $\mathrm{Bu}$ durum, bağlantıların hasar yükünü önemli ölçüde artırmıştır.

Akrilik esaslı yapıştırıcı (G-Force) kullanılarak üretilen tek tesirli bağlantı numunelerinin ortalama hasar yükleri Şekil 10'da verilmiştir. Sonuçlar incelendiğinde, yapıştırılan malzemelere uygulanan farklı yüzey işlemlerinin, bağlantıların hasar yükünü önemli miktarda değiştirdiği görülmektedir. 

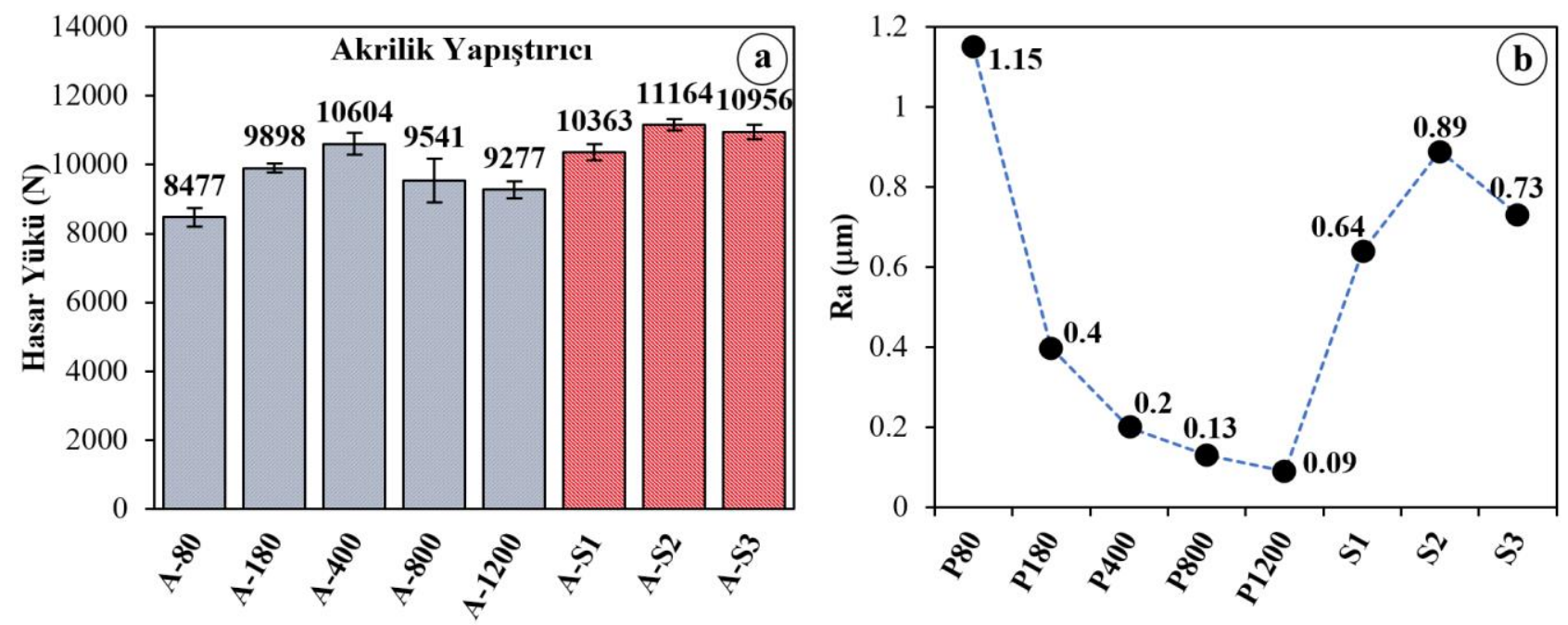

Şekil 10. (a) Akrilik yapıştırıcı (G-Force) ile birleştirilmiş bağlantıların ortalama hasar yükleri, (b) Yüzey pürüzlülük değerleri

Akrilik yapıştırıcı ile üretilen tek tesirli bağlantılarda, farklı boyutlardaki zımpara kağıtları ile aşındırılarak üretilen numunelerinin (A-80, A180, A-400, A-800 ve A-1200) çekme testi sonuçları incelendiğinde (Şekil 10), maksimum hasar yükünün $0.20 \mu \mathrm{m}$ Ra pürüzlülük değerinde elde edildiği görülmektedir. Elde edilen bu ortalama hasar yükü değerinin, $1.15 \mu \mathrm{m} \mathrm{Ra} \mathrm{(P80)}$ ve $0.40 \mu \mathrm{m} \mathrm{Ra}(\mathrm{P} 180)$ pürüzlülük değerine sahip bağlantı numunelerinden elde edilen ortalama hasar yükleri ile karşılaştırıldığında sırasıyla \%25 ve $\% 7$ oranında artış sağlandığı gözlemlenmiştir. $0,20 \mu \mathrm{m} \quad \mathrm{Ra}$ pürüzlülük değerine kadar artış gösteren hasar yükü değerleri daha sonrasında azalma eğilimi göstermiştir. Maksimum yüzey pürüzlülüğüne sahip $(1.15 \mu \mathrm{m} \mathrm{Ra})$ numuneler ile üretilen bağlantı numunelerinin ortalama hasar yükü, minimum yüzey pürüzlülügüne sahip (0.09 $\mu \mathrm{m} \mathrm{Ra)}$ numunelerin ortalama hasar yükü ile kıyaslandığında ise $\% 9$ oranında artış sağlandığı gözlemlenmiştir.

Kimyasal dağlama işlemleri uygulanarak üretilen tek tesirli bağlantı numunelerinin hasar yükleri göz önüne alındığında, $11164 \mathrm{~N}$ ortalama hasar yükü maksimum değer olup, S2 çözeltisi ile dağlama işlemi uygulanan $0.89 \mu \mathrm{m} \quad \mathrm{Ra}$ pürüzlülük değerlerine sahip bağlantı numunelerinde elde edilmiştir. $\mathrm{Bu}$ değer; $\mathrm{S} 1$ ve $\mathrm{S} 3$ dağlama işlemi sonras1 elde edilen 0.64 ve $0.73 \mu \mathrm{m} \mathrm{Ra}$ yüzey pürüzlülüğüne sahip numuneler kullanılarak üretilen bağlantıların ortalama hasar yükü ile kıyaslandığında sırasıyla yaklaşık $\% 5$ ve $\% 2$ oranında artış göstermiş̧ir.

Mekanik ve kimyasal yüzey işlemleri birlikte değerlendirildiğinde; maksimum hasar yükünün elde edildiği S2 dağlama işlemi, zımparalanmış numunelerin $1.15 \mu \mathrm{m} 0.40 \mu \mathrm{m}, 0.20 \mu \mathrm{m}, 0.13 \mu \mathrm{m}$, $0.09 \mu \mathrm{m}$ Ra pürüzlülük değerlerinde elde edilen ortalama hasar yükleri ile karşılaştırıldığında sırasıyla yaklaşık $\% 32, \% 13, \% 5, \% 17$ ve $\% 20$ oranlarında artış sağlamıştır.

Her iki yapıştırıcı ile üretilen tüm bağlantı numunelerinin sonuçları incelendiğinde, yapıştırma bağlantılarında en iyi sonucun optimize edilmiş sodyum dikromat/sülfirik asit dağlama işlemi (S2) uygulanarak üretilen bağlantılarda olduğu görülmektedir. Mekanik ve kimyasal yüzey işlemleri farklı yüzey morfolojileri oluşturmaktadır. Mekanik yüzey işlemleri, yapışma yüzeyinde oluşan, yapıştırıcı ile yüzeyin temasında arada engel işlevi gören oksit tabakanın kaldırılmasında yeterince etkili olamazlar. Yüzeyden oksit tabakanın kaldırılarak onun yerine daha ince ve aktif bir tabakanın yerleştirilmesinde dağlama işlemleri yaygın olarak uygulanmaktadır. $\mathrm{Bu}$ yüzden, dağlama işlemleri ile elde yapıştırma bağlantıları mekanik yüzey işlemlerine kıyasla daha yüksek yapışma dayanımı sergilemektedirler.

Ayrıca, mekanik yüzey hazırlığı uygulanmış numunelerin yüzey pürüzlülük değerleri ve hasar yükleri incelendiğinde, yapıştırıcının epoksi veya akrilik olmasına bağlı olarak, optimum pürüzlülük değeri farklılık göstermektedir. Safari ve arkadaşları tarafından yapılan çalışmada da farklı yapıştırıcıları kullanılmış ve optimum yüzey pürüzlülüğünün yapıştırıcıya bağlı olarak değiştiştiği ifade edilmiştir (Safari vd., 2020). Epoksi yapıştırıcılarda $0.13 \mu \mathrm{m}$ Ra değeri optimum pürüzlülük değeri iken, akrilik esaslı yapıştırıcılarda bu değer $0.20 \mu \mathrm{m} \quad$ Ra'dır. Yapıştırıcıların viskozite değerlerinin farklı değerde olması yüzey 1slatabilirliğini 
etkilemektedir. Nispeten yüksek viskozite değerine sahip epoksi yapıştırıcı $0.13 \mu \mathrm{m}$ Ra değerinde yapışma yüzeyine daha iyi nüfuz ederken, düşük viskoziteye sahip akrilik yapıştırıcı ise $0.2 \mu \mathrm{m} \mathrm{Ra}$ değerinde yapışma yüzeyini optimum oranda 1slatmaktadır.

\subsection{Hasar yüzeyleri}

Çekme yüküne maruz kalan tek tesirli bağlantı numunelerinde eğilme momenti oluşarak yapışma bölgesinin uç kısımlarında soyulma gerilmeleri meydana getirir. Bağlantılarda oluşan bu soyulma gerilmeleri hasara sebep olmaktadır. Yapıştırma bağlantılarında meydana gelen hasar, bindirme bölgesinin uç kısımlarından başlayarak yapışma alanının ortasına doğru hareket ederek oluşmaktadır.

Epoksi yapıştırıcıyla birleştirilmiş bağlantıların çekme deneyi sonrası hasar yüzeyleri Şekil 11'de verilmiştir. Hasar yüzeyleri incelendiğinde, her iki yapışma yüzeyinde de farklı oranlarda yapıştırıcı bulunduğu görülmektedir. Elde edilen bu hasar çeşidi özel kohezif hasar olarak isimlendirilmektedir.

E-80 hasar yüzeyi incelendiğinde, yapıştırıcının neredeyse tamamının alt yüzeyde kaldığı görülmektedir. Yapıştırma bağlantısı, uygulanan yükü orta kısma doğru taşıyamamış ve kopma gerçekleşmiştir. Elde edilen fazla pürüzlü yüzey, epoksinin yüzeyde oluşan gözeneklere nüfuz etmesini engelleyerek, yapıştırıcının yüzeyi 1slatmasına engel olmaktadır. Dolayısıyla mekanik kilitleme mekanizması çalışmamış ve yapışma tam olarak gerçekleşememiştir. Bu durum, en pürüzlü yüzeyin en yüksek dayanımı sergilemeyeceğinin bir göstergesidir. E-800 hasar yüzeyi incelendiğinde ise yapıştırıcının her iki yüzeyde de uç kısımlarda kaldığı ve hasar yükünün bağlantının orta kısmına taşındığı sonucuna ulaşılabilir. $\mathrm{Bu}$ sayede hasar yükünde artış sağlanmıştır.

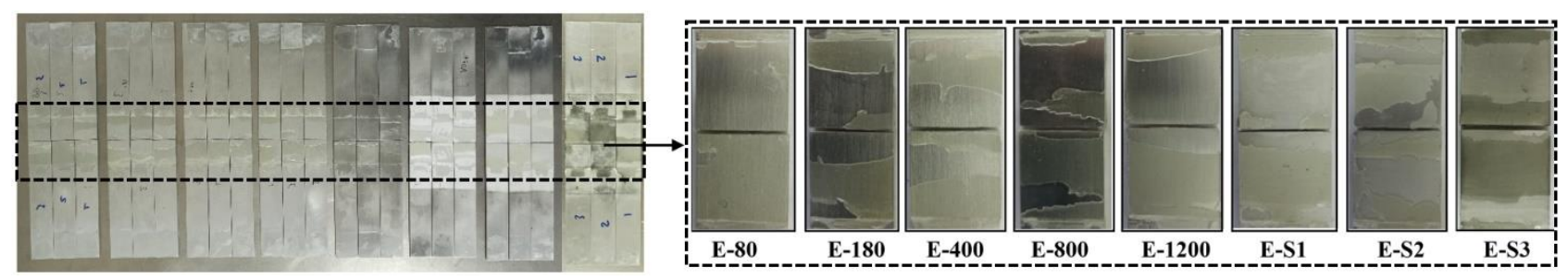

Şekil 11. Epoksi yapıştırıcı kullanılarak üretilen tek tesirli bağlantıların hasar yüzeyleri

S2 dağlama işlemi ile üretilen ve optimum yüzey pürüzlülüğü ile maksimum hasar yükü değeri elde edilen tek tesirli yapışma bağlantılarının hasar yüzeyini incelediğimizde ise, her iki yapışma yüzeyinin uç kısımlarının yapıştırıcı ile kaplandığ görülmektedir. Ayrıca, uygulanan dağlama işlemi sonras1 yüzeyin gözenekli hale gelerek yapıştırıcının etki ettiği yapışma alanını arttırması ve yapıştırıcının yüzeyi yüksek oranda 1slatabilmesinin bir sonucu olarak, hasara sebep olan çatlak, bindirme bölgesinin orta kısmına doğru bir noktada başlamıştır. Hasara sebep olan çatlağın orta kısma doğru ilerlemesi ile hasar yükünde maksimum değer elde edilmiştir. E-S1, ES2 ve E-S3 hasar yüzeyleri birlikte incelendiğinde ise; dağlama çözeltilerinin yapışma yüzeylerinde oluşturdukları ince oksit tabakanın S2 çözeltisi ile daha aktif ve daha gözenekli bir yüzey oluşturması nedeniyle, yüzeyinin sslanabilirliğinde artış sağlanmış ve daha yüksek oranda yapışma gerçekleşmiştir.

Akrilik yapıştırıcı kullanılarak üretilen tek tesirli bağlantıların hasar yüzeyleri Şekil 12'de verilmiştir. Hasar yüzeyleri incelendiğinde, epoksi kullanılarak üretilen bağlantılar ile benzer hasar yüzeyleri (özel kohezif hasar) gözlemlenmiştir.

Epoksi yapıştırıcı kullanılarak üretilen bağlantılar ile benzer şekilde, A-80 hasar yüzeyinde yapıştırıcının çoğunlukla alt yüzeyde kaldığı görülmektedir. Uygulanan hasar yükünün orta kısma doğru taşıyamadan kopan bağlantı düşük yapışma dayanımı sergilemiştir. A-180 ve A-800 hasar yüzeyleri incelendiğinde ise, yaklaşık olarak aynı ortalama hasar yükü değerine sahip bu iki bağlantıda benzer hasar gözlemlenmiştir. Bu iki bağlantıda yapıştırıcının, A-80 numunesine kıyasla hasar yükünü bindirme bölgesinin ortasına daha yüksek oranda taşıdığı görülmektedir. 


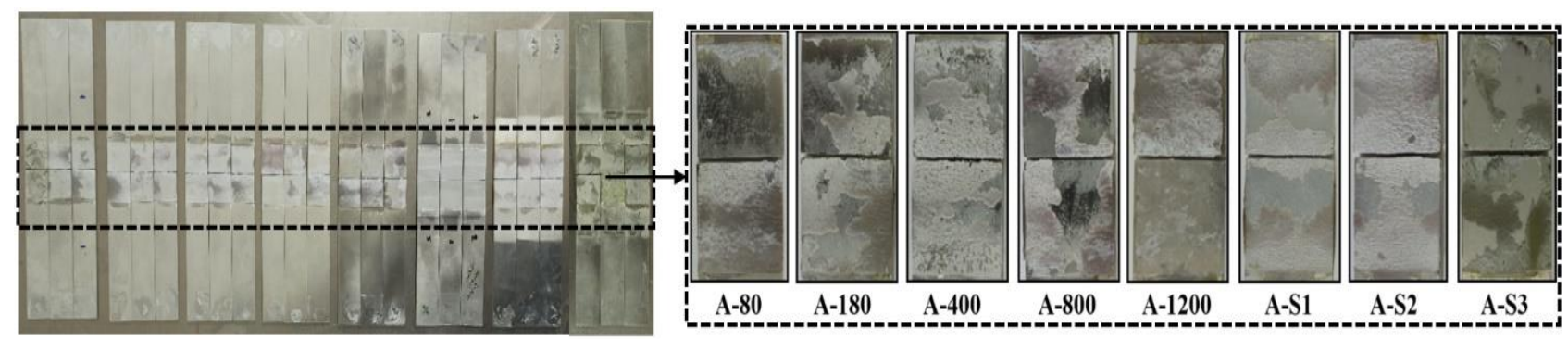

Şekil 12. Akrilik yapıştırıcı kullanılarak üretilen tek tesirli bağlantıların hasar yüzeyleri

Akrilik yapıştırıcı ile üretilen tek tesirli bağlantılarda, farklı zımpara boyutlarında elde edilen optimum yüzey pürüzlülüğünün $(0.20 \mu \mathrm{m}$ $\mathrm{Ra})$ ve maksimumum hasar yükünün $(10604 \mathrm{~N})$ elde edildiği A-400 bağlantısında, yapıştırıcının her iki yapışma yüzeyinde uç kısımlara tutunduğu görülmektedir. $\mathrm{Bu}$ nedenle $\mathrm{A}-400$ tek tesirli bağlantı numunesinin uygulanan yükü bağlantının orta kısmına taşınmada ve ortalama hasar yükünü arttırmada diğer numunelere kıyasla daha başarılı olduğu ifade edilebilir. Dağlama işlemleri ile üretilen tek tesirli bindirme bağlantıları incelendiğinde, epoksi ile üretilen bağlantılarla benzer şekilde A-S2 hasar yüzeyinin büyük çoğunluğunun yapıştırıcı ile kaplandığ 1 görülmektedir. Söz konusu durum, uygulanan üç farklı dağlama işlemi sonucunda elde edilen maksimum hasar yüküne sahip bu numunenin yüksek yapışma dayanımının bir göstergesidir. Tüm bağlantı numunelerinin hasar yüzeyleri ortalama hasar yükleri ile değerlendirildiğinde sonuçların birbiri ile uyumlu olduğu ifade edilebilir.

\section{Tartışma ve sonuçlar}

Yapılan çalışmada, farklı yüzey hazırlama işlemlerinin ve yüzey pürüzlülüğünün yapıştırma bağlantılarının hasar yüküne etkisi incelenmiştir. $\mathrm{Bu}$ amaçla AA2024-T3 alüminyum alaşımlarının yapışma yüzeyine mekanik (beş farklı boyutta zımparalama) ve kimyasal yüzey (sodyum dikromat/sülfürik asit (S1), optimize edilmiş sodyum dikromat/sülfürik asit (S2) ve ferrik sülfat/sülfürik asit (S3) dağlama) hazırlama işlemleri uygulanmıştır. Epoksi ve akrilik esaslı yapıştırıcılar ile hazırlanan numuneler kullanılarak tek tesirli bağlantı numuneleri üretilmiştir. Uygulanan farklı yüzey hazırlama işlemlerinin yapışma bağlantılarının mekanik özelliklerine etkisini incelemek amaciyla, hazırlanan bağlantı numuneleri çekme yükü altında test edilmiştir. Çalışmadan elde edilen sonuçlar aşağıda özetlenmiştir:
- Çift bileşenli epoksi ve akrilik yapısal yapıştırıcıları kullanılarak üretilen bağlantı numunelerinin hasar yükü, AA2024-T3 alaşımlarına uygulanan yüzey hazırlama methoduna ve yüzey pürüzlüğüne bağlı olarak değişmektedir.

- Epoksi yapıştırıcı kullanılarak üretilen yapıştırma bağlantılarında; P800 zımparalama işlemi ile elde edilen $0.13 \mu \mathrm{m}$ Ra pürüzlülük değerinde $8946 \mathrm{~N}$ maksimum hasar yükü değeri elde edilmiştir. Kimyasal yüzey hazırlama yönteminde ise; optimize edilmiş sodyum dikromat/sülfirik asit çözeltisi (S2) ile yapılan dağlama işlemi ile elde edilen $0.89 \mu \mathrm{m}$ Ra yüzey pürüzlülügüne sahip numuneler kullanılarak üretilen bağlantılarda $12956 \mathrm{~N}$ maksimum hasar yükü değeri elde edilmiştir. Epoksi yapıştırıcılarla birleştirilmiş bağlantılarda en etkili yüzey hazırlama yönteminin optimize edilmiş sodyum dikromat/sülfirik asit çözeltisi (S2) ile yapılan dağlama işlemi olduğu sonucuna varilabilir.

- Akrilik yapıştırıcı kullanılarak üretilen yapıştırma bağlantılarının hasar yükleri incelendiğinde ise; mekanik yüzey hazırlama işlemleri sonucu $0.2 \mu \mathrm{m} \quad \mathrm{Ra}$ pürüzlülük değerinde (P400) maksimum hasar yükü elde edilirken, kimyasal yüzey hazırlama işleminde ise $0.89 \mu \mathrm{m} \mathrm{Ra}$ pürüzülük değerinde (S2) maksimum hasar yükü elde edilmiştir.

- Her iki yapıştırıcı ile üretilen tüm bağlantı numunelerinin sonuçları incelendiğinde, yapıştırma bağlantılarında en iyi sonucun optimize edilmiş sodyum dikromat/sülfirik asit dağlama işlemi (S2) ile üretilen bağlantılarda olduğu görülmektedir.

- Mekanik yüzey hazırlığı uygulanmış numunelerin yüzey pürüzlülük değerleri ve hasar yükleri incelendiğinde, yapıştırıcının epoksi veya akrilik olmasına bağlı olarak, optimum pürüzlülük değeri farklılık göstermektedir. Epoksi yapıştırıcılarda $0.13 \mu \mathrm{m}$ 
Ra değeri optimum pürüzlülük değeri iken, akrilik esaslı yapıştırıcılarda bu değer $0.2 \mu \mathrm{m}$ Ra'dır.

- Hasar yüzeyleri incelendiğinde tüm bağlantılarda özel kohezif hasar oluştuğu gözlemlenmiştir. Tüm bağlantı numunelerinin hasar yüzeyleri ortalama hasar yükleri ile değerlendirildiğinde sonuçların birbiri ile uyumlu olduğu görülmüştür.

\section{Kaynaklar}

Adin, H. ve Turgut, A. (2013). The effects of width on the strength of adhesively bonded $\mathrm{z}$ joints subjected to tensile loads. The Journal of Adhesion, $\quad 89(1)$, 1-18. https://doi.org/10.1080/00218464.2012.725619

Adin, H. (2017). Effect of overlap length and scarf angle on the mechanical properties of different adhesive joints subjected to tensile loads. Materials Testing, 59(6), 536-546. https://doi.org/10.3139/120.111031

Adin, M. Ş. ve Kilıçkap, E. (2021). Strength of doublereinforced adhesive joints. Materials Testing, 63(2), 176-181. https://doi.org/10.1515/mt2020-0024

Boutar, Y., Naïmi, S., Mezlini, S. ve Ali, M. B. S. (2016). Effect of surface treatment on the shear strength of aluminium adhesive single-lap joints for automotive applications. International Journal of Adhesion \& Adhesive, 67, 38-43. http://dx.doi.org/10.1016/j.ijadhadh.2015.12.02 3

Cui, J., Wang, S., Wang, S., Chen, S. ve Li, G. (2020). Strength and failure analysis of adhesive singlelap joints under shear loading: effects of surface morphologies and overlap zone parameters. Journal of Manufacturing Processes, 56, 238247.

https://doi.org/10.1016/j.jmapro.2020.04.042

Ghumatkar, A., Sekhar, R. ve Budhe, S. (2017). Experimental study on different adherend surface roughness on the adhesive bond strength. Materials Today: Proceedings, 4(8), 7801-7809. https://doi.org/10.1016/j.matpr.2017.07.115

Golru, S.S., Attar, M. M. ve Ramezanzadeh, B. (2015). Effects of different surface cleaning procedures on the super ficial morphology and the adhesive strength of epoxy coating on aluminium alloy 1050. Progress in Organic Coatings, 87, 52-60. http://dx.doi.org/10.1016/j.porgcoat.2015.05.00 5

Grard, A., Belec, L. ve Perrin, F. X. (2020). Effect of surface morphology on the adhesion of silicone elastomers on AA6061 aluminum alloy.
International Journal of Adhesion and Adhesive, 102 , 102656. https://doi.org/10.1016/j.ijadhadh.2020.102656

Gültekin, K., Akpinar, S. ve Özel, A (2015) The effect of moment and flexural rigidity of adherend on the strength of adhesively bonded single lap joints. The Journal of Adhesion, 91(8), 637-650. https://doi.org/10.1080/00218464.2014.953674

Hirulkar, N. S., Jaiswal, P. R., Alessandro, P. ve Reis, P. (2018). Influence of mechanical surface treatment on the strength of mixed adhesive joint. Materials Today: Proceedings, 5, 18776-18788. https://doi.org/10.1016/j.matpr.2018.06.224

Jawade, S.A., Joshi, R.S. ve Desai, S. V. (2020). Comparative study of mechanical properties of additively manufactured aluminum alloy. Materials Today: Proceedings. https://doi.org/10.1016/j.matpr.2020.02.096

Kanani, A.Y., Hou, X. ve Ye, J. (2020). A novel dissimilar single-lap joint with interfacial stiffness improvement. Composite structures, 252 ,

112741 https://doi.org/10.1016/j.compstruct.2020.11274 1

Natalia, M. A., Goushegir, S. M., dos Santos, J. F., Canto, L. B. ve Amancio-Filho, S. T. (2016). Friction spot joining of aluminum alloy 2024-T3 and carbon-fiber-reinforced poly(phenylene sulfide) laminate with additional PPS film interlayer: Microstructure, mechanical strength and failure mechanisms. Composites Part B, 94, 197-208.

http://dx.doi.org/10.1016/j.compositesb.2016.03 .011

Özer, H. ve Erbayrak, E. (2016). Experimental investigation on the self-healing efficiency of Araldite 2011 adhesive reinforced with thermoplastic microparticles. Rudawska, A. (Ed.), Adhesives: Applications and properties (s. 169-185). London; IntechOpen. http://dx.doi.org/10.5772/62603

Saalema, N., Sarkar, D. K., Paynter, R. W., Gallant, D. ve Eskandarian, M. (2012). A simple surface treatment and characterization of AA 6061 aluminum alloy surface for adhesive bonding applications. Applied Surface Science, 261, 742748.

http://dx.doi.org/10.1016/j.apsusc.2012.08.091

Safari, A., Farahani, M. ve Ghabezi, P. (2020). Experimental study on the influences of different surface treatment processes and adhesive type on the aluminum adhesive-bonded joint strength. Mechanics Based Design of Structures and Machines, $1-14$. https://doi.org/10.1080/15397734.2020.1777876 
Salstela, J., Suvanto, M. ve Pakkanen, T. T. (2016). Influence of hierarchical micro-micro patterning and chemical modifications on adhesion between aluminum and epoxy. International Journal of Adhesion \& Adhesive, 66, 128-137. http://dx.doi.org/10.1016/j.ijadhadh.2015.12.03 6

Saraç, İ., Adin, H. ve Temiz, Ş. (2018). Experimental determination of the static and fatigue strength of the adhesive joints bonded by epoxy adhesive including different particles. Composites Part B: Engineering, 155, 92-103. https://doi.org/10.1016/j.compositesb.2018.08.0 06

Singh, S.S. ve Kitey, R. (2017). Effect of interface profile and incident wave characteristics on aluminum/epoxy dynamic adhesion strength. International Journal of Adhesion and Adhesive, 79, 8-17. http://dx.doi.org/10.1016/j.ijadhadh.2017.09.00 1

Wu, X., Zhan, L., Zhao, X., Wang, X. ve Chang, T. (2020). Effects of surface pre-treatment and adhesive quantity on interface characteristics of fiber metal laminates. Composite Interfaces, 27(9), 829-843. https://doi.org/10.1080/09276440.2019.1707023

Xing, Y., Yang, S., Lu, S., Zhang, P., An, Y. ve Zhai, J. (2020). Effect of bonding parameters on compression mechanical properties of bidirectional corrugated honeycomb aluminum. The Journal of Adhesion, 1-19. https://doi.org/10.1080/00218464.2020.1834388

Xu, Y., Li, H., Shen, Y., Liu, S., Wang, W. ve Tao, J. (2016). Improvement of adhesion performance between aluminum alloy sheet and epoxy based on anodizing technique. International Journal of Adhesion and Adhesives, 70, 74-80. http://dx.doi.org/10.1016/j.ijadhadh.2016.05.00 7

Zhang, J. Zhao, X., Zuo, Y. ve Xiong, J. (2008). The bonding strength and corrosion resistance of aluminum alloy by anodizing treatment in a phosphoric acid modified boric acid/sulfuric acid bath. Surface \& Coatings Technology, 202, 3149-3156.

http://dx.doi.org/10.1016/j.surfcoat.2007.10.041 